\title{
Potential targets and plausible drugs of Coronavirus infection caused by $2019-\mathrm{nCoV}$
}

\author{
Faezeh Almasi ${ }^{1}$ and Fatemeh Mohammadipanah ${ }^{1}$ \\ ${ }^{1}$ Affiliation not available
}

April 28, 2020

\begin{abstract}
The world is confronting a dire situation due to the recent pandemic of the novel coronavirus disease (2019-nCoV) with so far mortality cases of 100,000 all over the world. Currently, there are no effective enough treatment options for this previously unknown virus. The current drugs in pipline and some plausible drug are overviewed in this paper. The potential molecular targets of each steps of the 2019-nCoV drug life cycle is discussed and highlights here. Although different types of anti-viral targets are applicable for 2019-nCoV drug screenings, the more promising targets can be considered as protease and RNA polymerase. Based on the results from antiviral agents repurposing and clinical studies, the remdesivir could be an encouraging drug in the frontline to be administrated for 2019-nCoV. Much progress in understanding the 2019-nCoV the molecular details of its life cycle followed by the identification of therapeutic targets seems to be an efficient approach in discovering potential drugs.
\end{abstract}

\section{Hypothetical targets and plausible drugs of Coronavirus infection caused by 2019-nCoV}

Running Title: Drugs targets of 2019 novel coronavirus

Faezeh Almasi ${ }^{1}$ and Fatemeh Mohammadipanah ${ }^{*}$

${ }^{1}$ Pharmaceutical Biotechnology Lab, Department of Microbial Biotechnology, School of Biology and Center of Excellence in Phylogeny of Living Organisms, College of Science, University of Tehran, Tehran, Iran

Correspondence: Fatemeh Mohammadipanah

E-mail: fmohammadipanah@ut.ac.ir, Tel: +98 21 61113560, Fax: +98 2166412992

\section{Summary}

The world is confronting a dire situation due to the recent pandemic of the novel coronavirus disease (2019$\mathrm{nCoV}$ ) with the mortality rate passed over 150,000. Attaining efficient drugs evolve in parallel to the understanding of the 2019-nCoV pathogenesis. The current drugs in the pipeline and some plausible drugs are overviewed in this paper. Although different types of antiviral targets are applicable for 2019-nCoV drug screenings, the more promising targets can be considered as 3cl protease and RNA polymerase. The remdesivir could be considered the closest bifunctional drug to be provisional clinical administration for 2019$\mathrm{nCoV}$. The known molecular targets of the 2019-nCoV include fourteen targets while four molecules of ACE2, cathepsin L, 3cL protease and RdRp are suggessted as more promising potential targets. Accordingly, dual acting drugs as an encouraging solution in drug discovery is suggested. Emphasizing on the potential route of 2019-nCov infection and virus entry related factors like Integrins, cathepsin and ACE2 seems valuable. The potential molecular targets of each step of the 2019-nCoV life cycle are discussed and highlighted in this paper. Much progress in understanding the $2019-\mathrm{nCoV}$ the molecular details of its life cycle followed by the 
identification of new therapeutic targets needed to lead us to an efficient approach in anti-2019-nCoV drug discovery.

Keywords: Antivirals, Drug repurposing, Molecular targets, Novel coronavirus, 2019-nCoV, Proteases

\section{Introduction}

\subsection{Life cycle of the Coronavirus}

Coronaviruses (CoVs) are zoonotic, spherical (diameters of approximately 60-140 nm), positive-sense enveloped RNA viruses, belonging to the Coronaviridae family, including four genera of Alphacoronavirus , Betacoronavirus ,Deltacoronavirus , and Gammacoronavirus (Cascella et al., 2020; Li et al., 2019).

The betacoronavirus genome including 2019-nCoV comprises of the 5'-untranslated region (5'-UTR), 3'untranslated region (3'-UTR), open reading frame (ORF) 1a/b, structural proteins and accessory proteins. Sixteen non-structural proteins (nsp 1-16) are encoded through proteolytic processing (3CL and PL proteases) of the replicase polyproteins (ppla and pplab) encoded by the ORF1a/b. Nsps progress the formation of the replication-transcription complex and indirect escape from the host immune system (Chan et al., 2020).

The $\sim 30,000$ Nucleotide viral genome also, express four main structural proteins of spike (S), membrane (M), envelope (E), and nucleocapsid (N) encoded from the 3' end of the viral genome (Figure 1). The attachment of 2019-nCoV via the interaction of its S protein with angiotensin converting enzyme receptor on the host cell is the primary step in its life cycle and followed by proteolytic cleavage of S protein, the virus enters the cytosol. The second step is the expression of replicase proteins. Following replication and RNA synthesis (Third step) and assembly (last step), virions are released from the cell surface by exocytosis (Figure 2) (Fehr and Perlman, 2015).

\section{Current plausible drugs of 2019-nCoV}

\subsection{Potential drug compounds}

There are three lines of drug discovery approach to develop the novel drug for 2019-nCoV. These three approaches leading to the potential treatment options include drug repurposing, screening molecular databases using drug design tools and screening compound libraries in antiviral assays. By the time required to randomly screen the natural or chemical compound libraries, the third option is not compatible with the rapid rate of 2019-nCoV transmission in the community. Therefore, drug repurposing and computational docking analysis are the two main current approaches to find potential drugs for the treatment of $2019-\mathrm{nCoV}$.

The efficiency of seven antiviral drugs (ribavirin, penciclovir, nitazoxanide, nafamostat, chloroquine (CQ) remdesivir (RDV, GS-5734) and favipiravir (T-705) against a clinical isolate of 2019-nCoV are so far evaluated in the wet lab. These drugs have previously exhibited broad-spectrum antiviral activity against a diverse panel of RNA viruses such as SARS-CoV, MERS-CoV and Ebola virus (EBOV) (García-Serradilla et al., 2019). The recently investigated potential anti-2019-nCoV described in repurposing programs are summarized in Table 1. The cell culture investigations showed that the compounds chloroquine (CQ) and remdesivir (RDV) potently blocked virus infection at low-micromolar concentration with a high selectivity index (SI) (Wang et al., 2020).

\subsection{Potential drug candidates in clinical trials}

Remdesivir (GS-5734) is an adenosine analogue that has completed the phase III clinical trial for the treatment of Ebola virus infection. The antiviral drug remdesivir (GS-5734) is entered to the phase III clinical trials in Asian countries to assess the use of antiviral drug candidate for the potential treatment of coronavirus by Gilead Sciences. All reported potential drug candidates in clinical trials and their status are presented in Table 2. Moreover, multiple parallel attempts are in progress to develop 2019-nCoV vaccine. Currently 18 vaccine candidates are in preclinical phases and five candidates are in clinical phases (Table 3 ).

\section{Molecular targets of 2019-nCoV drug discovery}




\subsection{Host attachment and entry}

\subsubsection{Modification of host cell serine protease}

Despite the possibility of surface alteration of RNA viruses, blocking the viral receptor protein on the host cell surface, thereby inhibiting the virus entry, can be a proper option in the drug discovery process. Transmembrane Serine Protease 2 (TMPRSS2) that mediate the entry by distinct mechanisms. One is cleavage and activation of the spike glycoproteins of coronaviruses (like HCoV-229E and HCoV-EMC) which facilitates the virus-cell membrane entry. Conformational flexibility of S protein which is needed for fusion is facilitated by proteolytic cleavages (Bosch et al., 2003) which is catalyzed by TMPRSS2 as the most relevant cellular proteases in this process. Another mechanism is the proteolytic cleavage of angiotensin-converting enzyme 2 (ACE2), which might activate the coronavirus spike glycoprotein for cathepsin L-independent host cell entry.

\subsubsection{Angiotensin-converting enzyme 2 (ACE2)}

Angiotensin converting enzyme 2 (ACE2) is a type I membrane zinc metalloprotease mainly expressed in lung alveolar epithelial cells, enterocytes of the small intestine and arterial cells. ACE2 is able to hydrolyze angiotensin I to produce angiotensin (1-9) (Donoghue et al., 2000). The enzyme was known for its function as the virus receptor of SARS-CoV (Kuba et al., 2005) which was proved as the cellular receptor of 2019-nCov by Zhou et al (Zhou et al., 2020). Blocking the entrance of 2019-nCoV through this protein intervention seems to be a possible target for antiviral drug discovery.

\subsubsection{Integrins}

Recently, Sigrist et al suggested that 2019-nCoV may also use integrins as cell receptors in host cells, binding to them through a conserved RGD (403-405: Arg-Gly-Asp) motif in receptor-binding domain of S protein that is absent from other coronaviruses (Sigrist et al., 2020). The conformational changes due to ACE2 binding expose the RGD containing region. Different viruses like Ebola virus (Schornberg et al., 2009), human papillomavirus (Yoon et al., 2001), HIV-1 (Monini et al., 2012) and EBV (Tugizov et al., 2003) use integrins for cell attachment or entry. The antibody natalizumab ( $\alpha 4 \beta 1 / \beta 7$ integrin antagonist) for the treatment of multiple sclerosis/Crohn's disease and the small molecule tirofiban ( $\alpha$ IIb $\beta 3$ inhibitor) for the treatment of acute coronary syndrome are the known inhibitors of integrin (Ley et al., 2016). These studies confirm that inhibiting the integrin scan impede some coronaviruses from entering the host cells is considered as a prolific target for antiviral drug discovery.

\subsubsection{Host tyrosine kinase receptor}

Receptor tyrosine kinases (RTKs) are a group of growth factor receptors that are autophosphorylated after ligand binding (Lemmon and Schlessinger, 2010). Dong et al introduced an RTK inhibitor named (A9) as a robust inhibitor of transmissible gastroenteritis virus (TGEV) infection belong to Alphacoronavirus genera as a surrogate model for CoV in cell-based assays (Dong et al., 2020). The specific RTK inhibitors (RTKIs), known as AG879 and tyrphostin A9 (A9), are also reported as strong antiviral activity against the influenza A virus (Kumar et al., 2011). It was shown that blocking the receptor kinase activity by approved inhibitors broadly impair infection by all major HCV genotypes and viral escape variants in cell culture and in a human liver chimeric mouse model (Jilg and Chung, 2012). The tyrosine kinase inhibitor such as genistein can block the replication of HIV-1, herpes simplex virus type 1 (HSV-1) and Arenavirus (Vela et al., 2008). These findings suggest a potentially promising host-centered approach like RTKs to treat the 2019-nCoV.

\subsubsection{Viral spike protein}

The trimeric S glycoprotein responsible for the coronaviruses crown-like appearance, mediates attachment to the host receptor (Ou et al., 2020). Despite spike protein sequence similarity above $72 \%$ with SARS-CoV, a peculiar furin-like cleavage site at the S1/S2 position in the S-protein sequence of the 2019-nCoV was identified, lacking in the other SARS-like CoV (Coutard et al., 2020). Following the host cell attachment, entry is mediated by $\mathrm{S}$ protein priming by cellular protease. In some cases, the $\mathrm{S}$ protein is cleaved by a 
host cell furin-like protease. Blocking S protein attachment or furin-like cleavage sites are promising targets in drug discovery. Recently, Xia et al introduced a lipopeptide named EK1C4 effectively block 2019-nCoV infection at the cellular level in a dose-dependent manner with IC50 of $36.5 \mathrm{nM}$ (Xia et al., 2020). The presence of three vaccine candidates in clinical phases accentuates the importance of this protein in the process of drug development (Thanh et al., 2020).

\subsection{Inhibition of genome uncoating}

The cessation of the capsid disintegration by viral or host enzymes/proteins is a drug target used against the influenza virus, rhinoviruses, hepatitis A, poliovirus and enteroviruses (Yamauchi and Greber, 2016). In accordance with this approach, rimantadine disintegrates the viral capsid by blocking the ion channel in the influenza virus (Balgi et al., 2013). Maoto, a traditional Japanese herbal medicine also shows inhibitory activity on influenza virus A (PR8) presumed by inhibition of genome release (Masui et al., 2017).

No effort on blockage of uncoating step in the 2019-nCoV life cycle as a drug discovery target is reported so far. However, the S-protein-based vaccines can induce antibodies that block the genome uncoating besides the viral receptor blockage. Furthermore, it is still not determined whether the uncoating of 2019-nCoV can occurs in both acidic and neutral conditions similar to IBV or it is uncoating can be suppressed by the neutralization of the acidic condition of endosomes and its subsequent fusion.

\subsection{Inhibition of Replicase Protein Expression}

Following the uncoating step, the replicase gene of the viral genome encodes two large polyproteins (pp1a and pp1ab) (Chan et al., 2020). Then, viral proteinases perform post-translational modification on the polyproteins yielding proteins that mediate the formation of viral replication complexes. The protease activities for all coronaviruses include both papain-like proteinase (PLP) and cornavirus 3C-like proteinase activities that are encoded within the replicase polyproteins and mediate cleavage events. Because of their unique and essential function in processing the viral polyprotein, these proteases are appropriate targets for the development of 2019-nCoV drugs.

\subsubsection{Protease}

\subsubsection{Papain-like proteinase (PLpro)}

PLproteinase or nsp3 releases proteins is involved in both processes of coronavirus replication and infection of the host. Some studies have highlighted the importance of these protease inhibitors in other Coronaviruses. Ratia et al identified a compound, GRL0617, with an EC50 of $15 \mu \mathrm{M}$ that inhibits SARS-CoV viral replication in Vero E6 cells (Ratia et al., 2008). PLpro inhibitors against MERS-CoV (Kilianski et al., 2013), HEV (Saraswat et al., 2020), etc have also been reported. Disulfiram, an approved drug to treat alcohol dependence, has been reported to inhibit the papain-like protease of MERS and SARS in cell cultures, but clinical approval of its effectiveness is lacking ( $\mathrm{Li}$ and De Clercq, 2020). The inhibition of $\mathrm{Pl}$ pro can be considered as a promising target in the development of coronavirus drug discovery.

\subsubsection{3C-like main protease (3CLpro)}

3CLprotease (which is the main protease (Mpro)) or nsp5 directly mediates the processing of the viral polyprotein and maturation of viral nonstructural proteins (nsps), which are essential in the life cycle of the virus. Initiation of viral RNA synthesis and switching translation to RNA replication are other functions of this protein. 3CLpro is among the most attractive target for anti-coronavirus drug development. Based on a computational drug repurposing study performed by Junmei Wang (Wang, 2020), five drugs, namely, Carfilzomib, Eravacycline, Valrubicin, Lopinavir and Elbasvir, are identified to have inhibitory activities on $3 \mathrm{Cl}$ pro of 2019-nCoV. According to another computational study performed by Nguyen et al., Bortezomib, Flurazepam, Ponatinib, Sorafenib, Dasatinib, are five potent potential inhibitors of 3CL pro for 2019-nCoV (Nguyen et al., 2020).

Due to the similar active-site architecture of the 3C protease in coronaviruses and enteroviruses, Zhang et al designed peptidomimetic $\alpha$-ketoamides as suitable targets for the development of broad-spectrum antiviral 
drugs. They introduced a compound (11r) expecting to exhibit excellent antiviral activity against 2019-nCoV (Li and De Clercq, 2020; Zhang et al., 2020b)

\subsection{Replication of the CoV-19 genome}

\subsubsection{RNA-dependent RNA polymerase (RdRp)}

The most important conserved protein in the coronavirus replication/transcription complex is RNA-dependent RNA polymerase (RdRp) (nsp12) or RNA replicase (Gao et al., 2020). Genome multiplication is critical in the viral life cycle and can be an attractive target for the intervention in the infection progress.

The antiviral agents of remdesivir, favipiravir, penciclovir can inhibit the RNA-dependent RNA polymerase (RdRp) of many RNA viruses, specially the influenza virus. Wang et al. determined the efficiency of these agents on infected Vero E6 cells with 2019-nCoVBetaCoV (Li and De Clercq, 2020; Wang et al., 2020; Zhang et al., 2020b). The high concentrations of penciclovir $($ EC50 $=95.96 \mu \mathrm{M})$ and favipiravir $($ EC50 $=61.88$ $\mu \mathrm{M})$ were required to reduce the viral infection while remdesivir $(\mathrm{EC} 50=0.77 \mu \mathrm{M})$ potently blocked the virus infection at low-micromolar concentration.

\subsubsection{Helicase}

Helicase (nsp13) is a critical multi-functional protein required for virus replication containing two main domains; N-terminal metal binding domain (MBD) and a conserved helicase domain at the C-terminus (Hel). In positive-sense RNA viruses, the enzyme separates nucleic acid and unfold the highly stable secondary structures within the genomic RNA to increase the efficiency of its translation (Adedeji et al., 2012a). Despite the essential function of helicase in virus multiplication, a few potential inhibitors of nsp13 have been reported so far (Adedeji et al., 2012b; Shum and Tanner, 2008).

A 1,2,4-triazole derivative, SSYA10-001, has shown inhibition effect on both helicase of SARS-and MERSCoVs with EC50 values of $25 \mu \mathrm{M}$ and $7 \mu \mathrm{M}$, respectively (Adedeji et al., 2014). In another study, Yu et al demonstrated that myricetin and scutellarein can inhibit the SARS-CoV helicase protein by affecting the ATPase activity (Yu et al., 2012). The potent inhibition of the helicase activities and replication of SARS coronavirus with EC50 of less than $10 \mu \mathrm{M}$ is also reported by the Adamantane-derived Bananins (Tanner et al., 2005).

\subsubsection{The peptidyl/prolyl isomerases (PPIases)}

The 18-kDa cytosolic cyclophilin A is an essential cellular molecule required for replication of RNA viruses including HIV (Luban et al., 1993), HCV (Watashi et al., 2005), influenza A (Liu et al., 2012) and also coronavirus. Cyclophilins (Cyps), belonging to the family of peptidyl-prolyl isomerases (PPIases), catalyze the rate-limiting cis/trans isomerization step of proline-preceding peptide bonds during the protein folding. The PPIase activity is blocked by cyclosporin A and its different non-immunosuppressive analogs (de Wilde et al., 2018) such as Alisporivir (ALV; or Debio-025) (Landrieu et al., 2010), NIM811 (Ciechomska et al., 2005) and SCY-635 (Hopkins et al., 2010).

There are various reports indicating the effect of Cyps (de Wilde et al., 2011; Pfefferle et al., 2011) and its derivatives (Carbajo-Lozoya et al., 2014; de Wilde et al., 2017) on different genera of coronaviruses mainly MERS-CoV, HCoV-229E, HCoV-NL63 and SARS-CoV in cell culture.

\subsubsection{Nucleoside analog inhibitors}

Nucleoside analogs are dNTPs or rNTPs that lack 3'-OH group resulting in chain termination. They are widely used as a treatment for HBV, HCV, HIV-1, and HSV. Compared to the other RNA viruses, the proofreading activity of RdRp by the capability of 3' to 5' exoribonuclease (nsp14), leads up to 20-folds increase in accuracy of replication. The inhibitors enzyme of coronavirus is highly resistant to many nucleoside analogs including fabiravir (guanine analog), ribavirin (guanosine analog) and 5-fluorouracil (pyrimidine analog) (Harrison, 2020). 
Remdesivir, (adenosine analog) as a potent phosphoramidate prodrug is effective against filoviruses, pneumoviruses, and paramyxoviruses with two suggested mechanisms of action (Lo et al., 2017). One is being as nucleoside analog and the second is acting on viral RdRp. Accordingly, Peters et al evaluated the efficiency of a series of doubly flexible nucleoside analogues suggesting that compound 2 with EC50 $<10 \mu \mathrm{M}$ was promising against HCoV-NL63 (Peters et al., 2015). The combinations of nucleotide analoges can mitigate the resistance mediated by mutations in the viral RdRp, perhaps by additive or synergistic interactions effect (Pruijssers and Denison, 2019). Despite the proofreading activity, identifying nucleoside analog inhibitors hold promise for the treatment of $2019-\mathrm{nCoV}$.

\subsection{Viral protein assembly}

Capsid proteins have a pivotal function in the assembly of the virus, and interfering with the structure or function of these key proteins can be a solid antiviral strategy. Coronaviruses are distinct from other enveloped viruses in that they assemble at the intracellular membranes in the endoplasmic reticulum and golgi intermediate compartment (ERGIC) and transported out of the cell by exocytosis (Schoeman and Fielding, 2019). Envelope proteins (E) are clearly important for coronaviruses assembly, but their exact mechanistic role(s) is still not yet fully described (Schoeman and Fielding, 2019). Although E protein is abundantly expressed inside the infected cell, only a small portion is incorporated into the virion envelope and the major part is localized in intracellular trafficking, and participates in coronavirus assembly. The envelope protein (E) of coronaviruses (HCoV-229E, MHV, IBV) mediates viral assembly and form cationselective ion channels that their function is not clear (Wilson et al., 2004). Involvement of $\mathrm{E}$ protein in critical aspects of the viral life cycle, make 2019-nCoVs lacking E protein, a promising vaccine candidate. Pharmacological blockage of its assembly with acylguanidine, cinnamoylguanidine reduced the SARS-CoV and MHV viral titer by 76 and $88 \%$ at a concentration of $10 \mu \mathrm{M}$, respectively (Gage et al., 2007).

Qin et al. designed siRNAs that inhibit M protein expression through degradation of M mRNA in SARSassociated coronavirus, which provides an approach for studies on the functions of $\mathrm{M}$ protein and for the development of novel therapeutic agents for CoV infection (Qin et al., 2007)

Application of viral assemble inhibitors for different types of viruses including Mo-MLV (McNally et al., 2010), CSFV (Zhou et al., 2008), HIV-2 (Wu et al., 1995), HIV-1 (Li et al., 2009), DENV2 (Qin et al., 2005), HBV (Seo et al., 2019) and influenza A (Liu et al., 2014) is investigated. However, no drug candidate disparting the 2019-nCoV assembly is in the trial or is reported so far.

\subsection{Cell release of the virus}

Prevention of the release of the viruses from infected cells as the last step of the viral cycle, is an attractive strategy to limit the spread of the virus especially in pandemics. Drugs like zanamivir, oseltamivir, laninamivir octanoate and peramivir inhibit this step by targeting viral neuraminidase to block the release of Influenza virus (De Clercq and Li, 2016). Tetherin (bone marrow stromal cell antigen 2-BST-2, CD317) was discovered as the factor responsible for the defect in virion release of HIV-1 mutants lacking the accessory gene vpu (Van Damme et al., 2008).

One of the coronavirus virulence factors is ORF7a that inhibits the bone marrow matrix antigen 2 (BST-2) (Taylor et al., 2015) related to its escape from the innate immune system by host mRNA degradation and interferon production inhibition. Bone marrow matrix antigen 2 (BST-2), also known as tetherin or CD 317 , is a host protein constitutively expressed in mature B cells, plasma cells and plasmacytoid dendritic cells, that can inhibit the release of newly-assembled coronavirus from host cells. The evidence suggests that ORF7a may be a potential target for antiviral drug discovery of 2019-nCoV.

\section{Concluding remarks}

In the past twenty years, two new coronaviruses have been emerged mainly causing the acute respiratory syndrome coronavirus (SARS-CoV) and Middle East respiratory syndrome coronavirus (MERS-CoV) responsible for the epidemics in 2002 and 2012, respectively (World Health Organization, 2003; World Health 
Organization, 2013). Since the pandemic outbreak of novel coronavirus (2019-nCoV) and the rapidly increasing number of patients by minutes $(155175$ Deaths by April 18, 2020), the focus has been on the assessments to of recruite the existing antiviral compounds which must be complemented by the new drug discovery programs in the future. Nevertheless, the current urgent demand is addressing by the clinical trials of 30 drugs to approve the effectiveness of the existing antiviral drugs on 2019-nCoV.

The potential molecular targets in anti $2019-\mathrm{nCoV}$ drug discovery is surveyed in the paper that can be employed in HTS programs for systematic drug discovery for 2019-nCoV infection. Little is currently known about the biology of 2019-nCoV specially, viral protein synthesis and assembly and most of what we know have been for the last 4 months. Due to the high virus transmission and the global spread of coronavirus, the foremost controversial issue is the mitigation of its pathogenicity using the existing anti-viral compounds. Therefore, in silico or practical screening of molecular targets are being conducted on structural information obtained from all major variants of the virus. Although, the ongoing clinical trials are evaluating the potential treatments of more than 30 drugs, there are currently no specifically certified drugs or vaccines for 2019$\mathrm{nCoV}$. In addition to the above approach, detailed studying the viral life cycle can lead to assigning some even more effective drug targets. In this direction, some drug targets based on bioinformatics analysis and relative similarities of this new virus with other members of its family like host cell receptors, spike glycoproteins, papain-like and 3C-like protease, RdRp have been documented so far. However, an approximate half of the potent drug candidates and nearly one-third of the drugs registered on the www.clinicaltrials.gov webpage, solely inhibit proteases affecting the replicase protein expression step in the viral life cycle.

While full-length S proteins of 2019-nCoV and SARS-CoV share up to 76\% identities in amino acid sequences, the $\mathrm{N}$ terminal domain that binds to the receptor show only $53.5 \%$ of homology reflecting its ability to bind different sugars. Therefore, emphasizing on other virus entry related factors like cathepsin seems valuable for 2019-nCoV drug discovery. Based on a recent report (Walls et al., 2020), host proteases cathepsin L and TMPRSS2 prepare the 2019-nCoV S protein for cell entry. Considering the results of repurposing strategies and clinical tests until now, remdesivir seems a promising drug. Nevertheless, HIV protease inhibitors (ritonavir/lopinavir/ASC09), favipiravir and chloroquine need further investigations.

\section{Future directions}

As we proceed with the current molecular docking studies and presuming the effectiveness of the existing antiviral compounds, the de novo drug discovery will join to evaluate the modulation of the new molecular targets of 2019-nCoV in bioassay platforms which were discussed above and not only limited to 3cl pro and RdRpin. To accelerate the long, costly and rigorous process of drug discovery, high throughput methods and high content screening methods can be employed. However, by the immediate global need for drugs to control the COVID-19 infection drug search is currently pursued by the repurposing approach. Accordingly, the critical viral life cycle steps like entry, genome and protein synthesis reflect the multiple drug target groups that can be addressed by the conventional de novo strategy of drug discovery. Assembly and release inhibitors are less considered steps in 2019-nCov life cycle for its drug discovery. While most of the drug cases for 2019-nCoV are registered for the control purpose rather than prophylaxis; S protein, integrins and ACE2 targets are of value for drug repurposing or discovery programs to hinder the viral entry and fusion process. Considering the fact that the primary goal of all viruses is to deliver and replicate their genome to the competent host cells, blocking angiotensin-converting enzyme 2 (ACE2), cathepsin L, 3cL protease and RdRp are suggested to be promising targets for anti-2019-nCoV drug discovery.

\section{Acknowledgements}

This work was not funded. The authors have no relevant affiliations or financial involvement with any organization or entity with a financial interest in or financial conflict with the subject matter or materials discussed in the manuscript.

\section{Ethical Approval}

The authors confirm that the ethical policies of the journal, as noted on the journal's author guidelines page, 
have been adhered to. No ethical approval was required as this is a review article with no original research data.

\section{Conflict of Interest Statement}

Authors declare no conflict of interest on the data collected and interpreted in this paper.

Data Availability Statement

The paper is a review and doesn't have original experimental data to make them available

\section{References}

Adedeji, A. O., Marchand, B., te Velthuis, A. J., Snijder, E. J., Weiss, S., Eoff, R. L., Singh, K., and Sarafianos, S. G. (2012a). Mechanism of nucleic acid unwinding by SARS-CoV helicase. PloS One, 7. doi:10.1371/journal.pone.0036521

Adedeji, A. O., Singh, K., Calcaterra, N. E., DeDiego, M. L., Enjuanes, L., Weiss, S., and Sarafianos, S. G. (2012b). Severe acute respiratory syndrome coronavirus replication inhibitor that interferes with the nucleic acid unwinding of the viral helicase. Antimicrobial Agents And Chemotherapy, 56, 4718-4728. doi:

10.1128/AAC.00957-12

Adedeji, A. O., Singh, K., Kassim, A., Coleman, C. M., Elliott, R., Weiss, S. R., Frieman, M. B., and Sarafianos, S. G. (2014). Evaluation of SSYA10-001 as a replication inhibitor of SARS, MHV and MERS coronaviruses. Antimicrobial Agents And Chemotherapy, AAC-02994.doi: 10.1128/AAC.02994-14

Adem, S., Eyupoglu, V., Sarfraz, I., Rasul, A., and Ali, M. (2020). Identification of potent COVID-19 main protease (Mpro) inhibitors from natural polyphenols: An in silico strategy unveils a hope against CORONA. Preprints, doi:

\subsection{4/preprints202003.0333.v1}

Aly, O. M. (2020). Molecular docking reveals the potential of aliskiren, dipyridamole, mopidamol, rosuvastatin, rolitetracycline and metamizole to inhibit COVID-19 virus main protease. ChemRxiv. Preprint, doi:

\subsection{4/chemrxiv.12061302.v1}

AminJafari, A. and Ghasemi, S. (2020). The Possible of Immunotherapy for COVID-19: a Systematic Review. International Immunopharmacology, 83, 106455. doi: 10.1016/j.intimp.2020.106455

Arya, R., Das, A., Prashar, V., and Kumar, M. (2020). Potential inhibitors against papain-like protease of novel coronavirus (SARS-CoV-2) from FDA approved drugs. ChemRxiv. Preprint.

Balgi, A. D., Wang, J., Cheng, D. Y., Ma, C., Pfeifer, T. A., Shimizu, Y., Anderson, H. J., Pinto, L. H., Lamb, R. A., and DeGrado, W. F. (2013). Inhibitors of the influenza A virus M2 proton channel discovered using a high-throughput yeast growth restoration assay. PloS One, 8.doi:

\subsection{1/journal.pone.0055271}

Bosch, B. J., van der Zee, R., de Haan, C. A., and Rottier, P. J. (2003). The coronavirus spike protein is a class I virus fusion protein: structural and functional characterization of the fusion core complex. Journal Of Virology, 77, 8801-8811. doi:10.1128/JVI.77.16.8801-8811.2003

Carbajo-Lozoya, J., Ma-Lauer, Y., Malešević, M., Theuerkorn, M., Kahlert, V., Prell, E., von Brunn, B., Muth, D., Baumert, T. F., and Drosten, C. (2014). Human coronavirus NL63 replication is cyclophilin Adependent and inhibited by non-immunosuppressive cyclosporine A-derivatives including Alisporivir. Virus Research, 184, 44-53.

doi: 10.1016/j.virusres.2014.02.010 
Cascella, M., Rajnik, M., Cuomo, A., Dulebohn, S. C., and Di Napoli, R. (2020, April 6). Features, evaluation and treatment coronavirus (COVID-19) [in StatPearls]. Retrieved from

\section{https://www.ncbi.nlm.nih.gov/books/NBK554776/}

Chan, J. F.-W., Kok, K. H., Zhu, Z., Chu, H., To, K. K.-W., Yuan, S., and Yuen, K. Y. (2020). Genomic characterization of the 2019 novel human-pathogenic coronavirus isolated from a patient with atypical pneumonia after visiting Wuhan. Emerging Microbes \& Infections, 9, 221-236. doi: 10.1080/22221751.2020.1719902

Ciechomska, I., Legat, M., Golab, J., Wesolowska, A., Kurzaj, Z., Mackiewicz, A., and Kaminska, B. (2005). Cyclosporine A and its non-immunosuppressive derivative NIM811 induce apoptosis of malignant melanoma cells in in vitro and in vivo studies. International Journal Of Cancer, 117, 59-67. doi:10.1002/ijc.21153

Contini, A. (2020). Virtual screening of an FDA approved drugs database on two COVID-19 coronavirus proteins. ChemRxiv. Preprint, doi:10.26434/chemrxiv.11847381.v1 Coutard, B., Valle, C., de Lamballerie, X., Canard, B., Seidah, N. G., and Decroly, E. (2020). The spike glycoprotein of the new coronavirus 2019$\mathrm{nCoV}$ contains a furin-like cleavage site absent in $\mathrm{CoV}$ of the same clade. Antiviral Research, 176, 104742. doi:10.1016/j.antiviral.2020.104742

Dastan, F., Tabarsi, P., Marjani, M., Moniri, A., Hashemian, S. M., Tavakoli-Ardakani, M., and Saffaei, A. (2020). Thalidomide against Coronavirus Disease 2019 (COVID-19): A Medicine with a Thousand Faces. Iranian Journal Of Pharmaceutical Research, 1-2. doi:

10.22037/IJPR.2020.113369.14259

De Clercq, E. and Li, G. (2016). Approved antiviral drugs over the past 50 years. Clinical Microbiology Reviews, 29, 695-747.

\section{doi:10.1128/CMR.00102-15}

de Wilde, A. H., Falzarano, D., Zevenhoven-Dobbe, J. C., Beugeling, C., Fett, C., Martellaro, C., Posthuma, C. C., Feldmann, H., Perlman, S., and Snijder, E. J. (2017). Alisporivir inhibits MERS-and SARScoronavirus replication in cell culture, but not SARS-coronavirus infection in a mouse model. Virus Research, 228, 7-13. doi:

\subsection{6/j.virusres.2016.11.011}

de Wilde, A. H., Pham, U., Posthuma, C. C., and Snijder, E. J. (2018). Cyclophilins and cyclophilin inhibitors in nidovirus replication. Virology, 522, 46-55. doi:

\subsection{6/j.virol.2018.06.011}

de Wilde, A. H., Zevenhoven-Dobbe, J. C., van der Meer, Y., Thiel, V., Narayanan, K., Makino, S., Snijder, E. J., and van Hemert, M. J. (2011). Cyclosporin A inhibits the replication of diverse coronaviruses. The Journal Of General Virology, 92, 2542. doi:10.1099/vir.0.034983-0

Dong, W., Xie, W., Liu, Y., Sui, B., Zhang, H., Liu, L., Tan, Y., Tong, X., Fu, Z. F., and Yin, P. (2020). Receptor tyrosine kinase inhibitors block proliferation of TGEV mainly through p38 mitogen-activated protein kinase pathways. Antiviral Research, 173, 104651. doi:10.1016/j.antiviral.2019.104651

Donoghue, M., Hsieh, F., Baronas, E., Godbout, K., Gosselin, M., Stagliano, N., Donovan, M., Woolf, B., Robison, K., and Jeyaseelan, R. (2000). A novel angiotensin-converting enzyme-related carboxypeptidase (ACE2) converts angiotensin I to angiotensin 1-9. Circulation Research, 87, e1-e9. doi:10.1161/01.res.87.5.e1

Elfiky, A. A. and Ibrahim, N. S. (2020). Anti-SARS and Anti-HCV Drugs Repurposing Against the Papainlike Protease of the Newly Emerged Coronavirus (2019-nCoV). Research Square, Preprint. doi:10.21203/rs.2.23280/v1

Fehr, A. R. and Perlman, S. (2015). Coronaviruses: an overview of their replication and pathogenesis in Coronaviruses. Springer, 1282,1-23.doi: 10.1007/978-1-4939-2438-7_1 
Gage, P., Ewart, G., Wilson, L., Best, W., and Premkumar, A. (2007). Antiviral compounds and methods [Google Patents. No, US20020111382A1]. Retrieved from https://patents.google.com/patent/US20020111382A1/en

Gao, Y., Yan, L., Huang, Y., Liu, F., Zhao, Y., Cao, L., Wang, T., Sun, Q., Ming, Z., and Zhang, L. (2020). Structure of the RNA-dependent RNA polymerase from COVID-19 virus. Science, eabb7498. doi:

\subsection{6/science.abb7498}

García-Serradilla, M. s., Risco, C., and Pacheco, B. (2019). Drug repurposing for new, efficient, broad spectrum antivirals. Virus Research,15,22-31. doi:

10.1016/j.virusres.2019.02.011

Harrison, C. (2020). Coronavirus puts drug repurposing on the fast track. Nature Biotechnology, 38, 379-381. doi:

\subsection{8/d41587-020-00003-1}

Hopkins, S., Scorneaux, B., Huang, Z., Murray, M. G., Wring, S., Smitley, C., Harris, R., Erdmann, F., Fischer, G., and Ribeill, Y. (2010). SCY-635, a novel nonimmunosuppressive analog of cyclosporine that exhibits potent inhibition of hepatitis $\mathrm{C}$ virus RNA replication in vitro, Antimicrobial Agents And Chemotherapy, 54, 660-672. doi:

\subsection{8/AAC.00660-09}

Jilg, N. and Chung, R. T. (2012). Adding to the toolbox: Receptor tyrosine kinases as potential targets in the treatment of hepatitis C. Journal Of Hepatology, 56, 282-284. doi:

10.1016/j.jhep.2011.06.020

Jin, Z., Du, X., Xu, Y., Deng, Y., Liu, M., Zhao, Y., Zhang, B., Li, X., Zhang, L., and Duan, Y. (2020). Structure-based drug design, virtual screening and high-throughput screening rapidly identify antiviral leads targeting COVID-19. BioRxiv. doi:

\subsection{1/2020.02.26.964882}

Khalili, J. S., Zhu, H., Mak, A., Yan, Y., and Zhu, Y. (2020). Novel coronavirus treatment with ribavirin: Groundwork for evaluation concerning COVID-19. Journal Of Medical Virology. doi:

\subsection{2/jmv.25798}

Kilianski, A., Mielech, A. M., Deng, X., and Baker, S. C. (2013). Assessing activity and inhibition of Middle East respiratory syndrome coronavirus papain-like and 3C-like proteases using luciferase-based biosensors. Journal Of Virology, 87, 11955-11962. doi:

\subsection{8/JVI.02105-13}

Kuba, K., Imai, Y., Rao, S., Gao, H., Guo, F., Guan, B., Huan, Y., Yang, P., Zhang, Y., and Deng, W. (2005). A crucial role of angiotensin converting enzyme 2 (ACE2) in SARS coronavirus-induced lung injury. Nature Medicine, 11, 875-879. doi:

\section{$10.1038 / \mathrm{nm} 1267$}

Kumar, N., Liang, Y., Parslow, T. G., and Liang, Y. (2011). Receptor tyrosine kinase inhibitors block multiple steps of influenza a virus replication. Journal Of Virology, 85, 2818-2827. doi:10.1128/JVI.01969-10

Landrieu, I., Hanoulle, X., Bonachera, F., Hamel, A., Sibille, N., Yin, Y., Wieruszeski, J. M., Horvath, D., Wei, Q., and Vuagniaux, G. g. (2010). Structural basis for the non-immunosuppressive character of the cyclosporin A analogue Debio 025. Biochemistry, 49, 4679-4686.doi: 10.1021/bi1003266

Lemmon, M. A. and Schlessinger, J. (2010). Cell signaling by receptor tyrosine kinases. Cell, 141, 1117-1134. 


\section{doi:10.1016/j.cell.2010.06.011}

Ley, K., Rivera-Nieves, J., Sandborn, W. J., and Shattil, S. (2016). Integrin-based therapeutics: biological basis, clinical use and new drugs. Nature Reviews Drug Discovery, 15, 173. doi:10.1038/nrd.2015.10

Li, G. and De Clercq, E. (2020). Therapeutic options for the 2019 novel coronavirus (2019-nCoV). Nature Reviews Drug Discovery, 19, 149-150.doi:10.1038/d41573-020-00016-0

Li, J., Tan, Z., Tang, S., Hewlett, I., Pang, R., He, M., He, S., Tian, B., Chen, K., and Yang, M. (2009). Discovery of dual inhibitors targeting both HIV-1 capsid and human cyclophilin A to inhibit the assembly and uncoating of the viral capsid. Bioorganic \& Medicinal Chemistry, 17, 3177-3188. doi:10.1016/j.bmc.2009.02.051

Li, X., Luk, H. K., Lau, S. K., and Woo, P. C. (2019). Human Coronaviruses: General Features. Reference Module In Biomedical Sciences, 2019. doi:10.1016/B978-0-12-801238-3.95704-0

Liu, G., Xiang, Y., Guo, C., Pei, Y., Wang, Y., and Kitazato, K. (2014). Cofilin-1 is involved in regulation of actin reorganization during influenza A virus assembly and budding. Biochemical And Biophysical Research Communications, 453, 821-825. doi:

10.1016/j.bbrc.2014.10.036

Liu, X., Zhao, Z., Xu, C., Sun, L., Chen, J., Zhang, L., and Liu, W. (2012). Cyclophilin A restricts influenza A virus replication through degradation of the M1 protein. PloS One, 7. doi:

\subsection{1/journal.pone.0031063}

Liu, X. and Wang, X. J. (2020). Potential inhibitors for 2019-nCoV coronavirus M protease from clinically approved medicines. BioRxiv, Preprint. doi: 10.1101/2020.01.29.924100

Lo, M. K., Jordan, R., Arvey, A., Sudhamsu, J., Shrivastava-Ranjan, P., Hotard, A. L., Flint, M., McMullan, L. K., Siegel, D., and Clarke, M. O. (2017). GS-5734 and its parent nucleoside analog inhibit Filo-, Pneumo-, and Paramyxoviruses. Scientific Reports, 7, 43395. doi:10.1038/srep43395

Loginova, S. I., Borisevich, S. V., Maksimov, V. A., Bondarev, V. P., Kotovskaia, S. K., Rusinov, V. L., Charushin, V. N., and Chupakhin, O. N. (2011). Therapeutic efficacy of Triazavirin, a novel Russian chemotherapeutic, against influenza virus A (H5N1). Antibiot Khimioter, 56, 10-12.

Luban, J., Bossolt, K. L., Franke, E. K., Kalpana, G. V., and Goff, S. P. (1993). Human immunodeficiency virus type 1 Gag protein binds to cyclophilins A and B. Cell, 73, 1067-1078. doi:10.1016/0092-8674(93)906376

Masui, S., Nabeshima, S., Ajisaka, K., Yamauchi, K., Itoh, R., Ishii, K., Soejima, T., and Hiromatsu, K. (2017). Maoto, a traditional Japanese herbal medicine, inhibits uncoating of influenza virus. Evidence-Based Complementary And Alternative Medicine, 2017. doi:10.1155/2017/1062065

Matsuyama, S., Kawase, M., Nao, N., Shirato, K., Ujike, M., Kamitani, W., Shimojima, M., and Fukushi, S. (2020). The inhaled corticosteroid ciclesonide blocks coronavirus RNA replication by targeting viral NSP15. BioRxiv, Preprint. doi: 10.1101/2020.03.11.987016

McNally, M. M., Wahlin, K. J., and Canto-Soler, M. V. (2010). Endogenous expression of ASLV viral proteins in specific pathogen free chicken embryos: relevance for the developmental biology research field. BMC Developmental Biology, 10, 106. doi:

10.1186/1471-213X-10-106

Monini, P., Cafaro, A., Srivastava, I. K., Moretti, S., Sharma, V. A., Andreini, C., Chiozzini, C., Ferrantelli, F., Cossut, M. R. P., and Tripiciano, A. (2012). HIV-1 tat promotes integrin-mediated HIV transmission to dendritic cells by binding Env spikes and competes neutralization by anti-HIV antibodies. PloS One, 7. doi:

10.1371/journal.pone.0048781 
Nguyen, D., Gao, K., Chen, J., Wang, R., and Wei, G. (2020). Potentially highly potent drugs for 2019-nCoV. BioRxiv, Preprint. doi:

\subsection{1/2020.02.05.936013}

Ou, X., Liu, Y., Lei, X., Li, P., Mi, D., Ren, L., Guo, L., Guo, R., Chen, T., and Hu, J. (2020). Characterization of spike glycoprotein of SARS-CoV-2 on virus entry and its immune cross-reactivity with SARS-CoV. Nature Communications, 11, 1-12.

\section{doi:10.1038/s41467-020-15562-9}

Peters, H. L., Jochmans, D., de Wilde, A. H., Posthuma, C. C., Snijder, E. J., Neyts, J., and Seley-Radtke, K. L. (2015). Design, synthesis and evaluation of a series of acyclic fleximer nucleoside analogues with anticoronavirus activity. Bioorganic \& Medicinal Chemistry Letters, 25, 2923-2926. doi: 10.1016/j.bmcl.2015.05.039

Pfefferle, S., Schöpf, J., Kögl, M., Friedel, C. C., Müller, M. A., Carbajo-Lozoya, J., Stellberger, T., von Dall'Armi, E., Herzog, P., and Kallies, S. (2011). The SARS-coronavirus-host interactome: identification of cyclophilins as target for pan-coronavirus inhibitors. PLoS Pathogens, 7. doi:

10.1371/journal.ppat.1002331

Pruijssers, A. J. and Denison, M. R. (2019). Nucleoside analogues for the treatment of coronavirus infections. Current Opinion In Virology, 35, 57-62. doi: 10.1016/j.coviro.2019.04.002

Qin, C. F., Qin, E., Yu, M., Chen, S. P., Jiang, T., Deng, Y. Q., Duan, H. Y., and Zhao, H. (2005). Therapeutic effects of dengue 2 virus capsid protein and staphylococcal nuclease fusion protein on dengue-infected cell cultures. Archives Of Virology, 150, 659-669. doi:

\section{$10.1007 / s 00705-004-0451-3$}

Qin, Z. 1., Zhao, P., Cao, M. m., and Qi, Z. t. (2007). siRNAs targeting terminal sequences of the SARSassociated coronavirus membrane gene inhibit $\mathrm{M}$ protein expression through degradation of $\mathrm{M}$ mRNA. Journal Of Virological Methods, 145, 146-154. doi:10.1016/j.jviromet.2007.05.017

Ratia, K., Pegan, S., Takayama, J., Sleeman, K., Coughlin, M., Baliji, S., Chaudhuri, R., Fu, W., Prabhakar, B. S., and Johnson, M. E. (2008). A noncovalent class of papain-like protease/deubiquitinase inhibitors blocks SARS virus replication. Proceedings Of The National Academy Of Sciences, 105, 16119-16124. doi:10.1073/pnas.0805240105

Richardson, P., Griffin, I., Tucker, C., Smith, D., Oechsle, O., Phelan, A., and Stebbing, J. (2020). Baricitinib as potential treatment for 2019-nCoV acute respiratory disease. Lancet, 395, e30. doi:

\subsection{6/S0140-6736(20)30304-4}

Rosa, S. G. V. and Santos, W. C. (2020). Clinical trials on drug repositioning for COVID-19 treatment. Revista Panamericana de Salud Pública, 44. doi:10.26633/RPSP.2020.40

Saraswat, S., Chaudhary, M., and Sehgal, D. (2020). Hepatitis E Virus Cysteine Protease Has Papain Like Properties Validated by in silico Modeling and Cell-Free Inhibition Assays. Frontiers In Cellular And Infection Microbiology, 9, 478. doi:

\subsection{9/fcimb.2019.00478}

Schoeman, D. and Fielding, B. C. (2019). Coronavirus envelope protein: current knowledge. Virology Journal, 16, 69. doi:

\subsection{6/s12985-019-1182-0}

Schornberg, K. L., Shoemaker, C. J., Dube, D., Abshire, M. Y., Delos, S. E., Bouton, A. H., and White, J. M. (2009). $\alpha 5$ $\beta 1$-Integrin controls ebolavirus entry by regulating endosomal cathepsins. Proceedings Of The National Academy Of Sciences, 106, 8003-8008. doi:10.1073/pnas.0807578106 
Seo, H. W., Seo, J. P., Cho, Y., Ko, E., Kim, Y. J., and Jung, G. (2019). Cetylpyridinium chloride interaction with the hepatitis B virus core protein inhibits capsid assembly. Virus Research, 263, 102-111.doi: 10.1016/j.virusres.2019.01.004

Shah, B., Modi, P., and Sagar, S. R. (2020) In silico studies on therapeutic agents for COVID-19: Drug repurposing approach. Life Sciences, 117652.doi: 10.1016/j.lfs.2020.117652

Shum, K. T. and Tanner, J. A. (2008). Differential inhibitory activities and stabilisation of DNA aptamers against the SARS coronavirus helicase. Chembiochem, 9, 3037-3045. doi:

10.1002/cbic.200800491

Sigrist, C. J., Bridge, A., and Le Mercier, P. (2020). A potential role for integrins in host cell entry by SARS-CoV-2. Antiviral Research, 177, 104759. doi: 10.1016/j.antiviral.2020.104759

Smith, M. and Smith, J. C. (2020). Repurposing therapeutics for covid-19: Supercomputer-based docking to the sars-cov-2 viral spike protein and viral spike protein-human ace2 interface. ChemRxiv, Preprint. doi:10.26434/chemrxiv.11871402.v4

Stebbing, J., Phelan, A., Griffin, I., Tucker, C., Oechsle, O., Smith, D., and Richardson, P. (2020). COVID19: combining antiviral and anti-inflammatory treatments. The Lancet Infectious Diseases, 20, 400-402. doi: 10.1016/S1473-3099(20)30132-8

Stower, H. (2020). Lopinavir-itonavir in severe COVID-19. Nature Medicine, 1. doi:10.1056/NEJMoa2001282

Talluri, S. (2020). Virtual Screening Based Prediction of Potential Drugs for COVID-19.Preprints, 2020020418. doi:

10.20944/preprints202002.0418.v2

Tanner, J. A., Zheng, B. J., Zhou, J., Watt, R. M., Jiang, J. Q., Wong, K. L., Lin, Y. P., Lu, L. Y., He, M. L., and Kung, H. F. (2005). The adamantane-derived bananins are potent inhibitors of the helicase activities and replication of SARS coronavirus. Chemistry \& Biology, 12, 303-311. doi:

\subsection{6/j.chembiol.2005.01.006}

Taylor, J. K., Coleman, C. M., Postel, S., Sisk, J. M., Bernbaum, J. G., Venkataraman, T., Sundberg, E. J., and Frieman, M. B. (2015). Severe acute respiratory syndrome coronavirus ORF7a inhibits bone marrow stromal antigen 2 virion tethering through a novel mechanism of glycosylation interference. Journal Of Virology, 89, 11820-11833.doi: 10.1128/JVI.02274-15

Thanh, L. T., Andreadakis, Z., Kumar, A., Gómez, R. R., Tollefsen, S., Saville, M., and Mayhew, S. (2020). The COVID-19 vaccine development landscape. Nature reviews Drug discovery. doi:

10.1038/d41573-020-00073-5

Touret, F. and de Lamballerie, X. (2020). Of chloroquine and COVID-19. Antiviral Research, 177,104762. doi:

\subsection{6/j.antiviral.2020.104762}

Tugizov, S. M., Berline, J. W., and Palefsky, J. M. (2003). Epstein-Barr virus infection of polarized tongue and nasopharyngeal epithelial cells. Nature Medicine, 9, 307-314. doi: 10.1038/nm830

Van Damme, N., Goff, D., Katsura, C., Jorgenson, R. L., Mitchell, R., Johnson, M. C., Stephens, E. B., and Guatelli, J. (2008). The interferon-induced protein BST-2 restricts HIV-1 release and is downregulated from the cell surface by the viral Vpu protein. Cell Host \& Microbe, 3, 245-252. doi:

10.1016/j.chom.2008.03.001 
Vela, E. M., Bowick, G. C., Herzog, N. K., and Aronson, J. F. (2008). Genistein treatment of cells inhibits arenavirus infection. Antiviral Research, 77, 153-156. doi:10.1016/j.antiviral.2007.09.005

Walls, A. C., Park, Y. J., Tortorici, M. A., Wall, A., McGuire, A. T., and Veesler, D. (2020). Structure, function, and antigenicity of the SARS-CoV-2 spike glycoprotein. Cell, 181, 281-292. doi:

10.1016/j.cell.2020.02.058

Wang, J. (2020). Fast Identification of Possible Drug Treatment of Coronavirus Disease-19 (COVID-19) Through Computational Drug Repurposing Study. ChemRxiv, Preprint. doi:

\subsection{4/chemrxiv.11875446.v1}

Wang, M., Cao, R., Zhang, L., Yang, X., Liu, J., Xu, M., Shi, Z., Hu, Z., Zhong, W., and Xiao, G. (2020). Remdesivir and chloroquine effectively inhibit the recently emerged novel coronavirus (2019-nCoV) in vitro. Cell Research, 30, 269-271. doi:

\section{$10.1038 / \mathrm{s} 41422-020-0282-0$}

Watashi, K., Ishii, N., Hijikata, M., Inoue, D., Murata, T., Miyanari, Y., and Shimotohno, K. (2005). Cyclophilin B is a functional regulator of hepatitis C virus RNA polymerase. Molecular Cell, 19, 111122.doi:10.1016/j.molcel.2005.05.014

Wilson, L., Mckinlay, C., Gage, P., and Ewart, G. (2004). SARS coronavirus E protein forms cation-selective ion channels. Virology, 330, 322-331. doi:

\subsection{6/j.virol.2004.09.033}

World Health Organization. (2003). Severe Acute Respiratory Syndrome (SARS) in Taiwan, China. Retrieved from https://www.who.int/csr/don/2003_12_17/en/

World Health Organization. (2013). Novel coronavirus infection-update. Retrieved from https://www.who.int/csr/don/2012_$11 \_30 / \mathrm{en} /$

Wu, X., Liu, H., Xiao, H., Kim, J., Seshaiah, P., Natsoulis, G., Boeke, J. D., Hahn, B. H., and Kappes, J. C. (1995). Targeting foreign proteins to human immunodeficiency virus particles via fusion with Vpr and Vpx. Journal Of Virology, 69, 3389-3398.

Xia, S., Liu, M., Wang, C., Xu, W., Lan, Q., Feng, S., Qi, F., Bao, L., Du, L., and Liu, S. (2020). Inhibition of SARS-CoV-2 infection (previously 2019-nCoV) by a highly potent pan-coronavirus fusion inhibitor targeting its spike protein that harbors a high capacity to mediate membrane fusion. Cell Research, 30, 343-355. doi:10.1038/s41422-020-0305-x

Xu, Z., Peng, C., Shi, Y., Zhu, Z., Mu, K., Wang, X., and Zhu, W. (2020). Nelfinavir was predicted to be a potential inhibitor of 2019-nCov main protease by an integrative approach combining homology modelling, molecular docking and binding free energy calculation: BioRxiv, Preprint. doi: 10.1101/2020.01.27.921627

Yamauchi, Y. and Greber, U. F. (2016). Principles of virus uncoating: cues and the snooker ball. Traffic, 17, 569-592. doi:

\section{$10.1111 / \operatorname{tra} .12387$}

Yang, L., Li, Z., Bai, T., and Hou, X. (2020). Discovery of potential drugs for COVID-19 based on the connectivity map. Research Square.doi:10.21203/rs.2.24684/v1

Yoon, C. S., Kim, K. D., Park, S. N., and Cheong, S. W. (2001). $\alpha 6$ integrin is the main receptor of human papillomavirus type 16 VLP. Biochemical And Biophysical Research Communications, 283, 668673.doi:10.1006/bbrc.2001.4838 
Yu, M. S., Lee, J., Lee, J. M., Kim, Y., Chin, Y. W., Jee, J. G., Keum, Y. S., and Jeong, Y. J. (2012). Identification of myricetin and scutellarein as novel chemical inhibitors of the SARS coronavirus helicase, nsP13. Bioorganic \& Medicinal Chemistry Letters, 22, 4049-4054. doi: 10.1016/j.bmcl.2012.04.081

Zhai, P., Ding, Y., Wu, X., Long, J., Zhong, Y., and Li, Y. (2020). The epidemiology, diagnosis and treatment of COVID-19. International Journal of Antimicrobial Agents, 105955. doi:10.1016/j.ijantimicag.2020.105955

Zhang, J., Ma, X., Yu, F., Liu, J., Zou, F., Pan, T., and Zhang, H. (2020a). Teicoplanin potently blocks the cell entry of 2019-nCoV. BioRxiv, Preprint. doi: 10.1101/2020.02.05.935387

Zhang, L. and Liu, Y. (2020). Potential interventions for novel coronavirus in China: a systemic review. Journal Of Medical Virology.doi:10.1002/jmv.25707

Zhang, L., Lin, D., Kusov, Y., Nian, Y., Ma, Q., Wang, J., von Brunn, A., Leyssen, P., Lanko, K., and Neyts, J. (2020b). $\alpha$-Ketoamides as broad-spectrum inhibitors of coronavirus and enterovirus replication: Structure-based design, synthesis, and activity assessment. Journal Of Medicinal Chemistry. doi:

10.1021/acs.jmedchem.9b01828

Zhou, B., Liu, K., and Chen, P. Y. (2008). Establishment and identification of classical swine fever virus (CSFV) capsid targeted nuclease expression system. Chinese journal of virology, 24, 451-455.

Zhou, P., Yang, X. L., Wang, X. G., Hu, B., Zhang, L., Zhang, W., Si, H. R., Zhu, Y., Li, B., and Huang, C. L. (2020). A pneumonia outbreak associated with a new coronavirus of probable bat origin. Nature, 579, 270-273. doi: 10.1038/s41586-020-2012-7

Table 1. Potential repurposing candidates with effectiveness on novel coronavirus 2019 (2019-n CoV). ND: Not Determined

\begin{tabular}{|c|c|c|c|}
\hline Drug candidate & Target & $\begin{array}{l}\text { Antiviral mechanism of } \\
\text { action }\end{array}$ & References \\
\hline Remdesivir & RNA polymerase & $\begin{array}{l}\text { Prodrug of an adenine } \\
\text { analog that } \\
\text { incorporates into } \\
\text { nascent viral RNA } \\
\text { chains and results in } \\
\text { pre-mature termination }\end{array}$ & (Wang et al., 2020) \\
\hline Baloxavir marboxil & RNA polymerase & $\begin{array}{l}\text { Cap-dependent } \\
\text { endonuclease inhibitor }\end{array}$ & (Harrison, 2020) \\
\hline Triazavirin & RNA polymerase & $\begin{array}{l}\text { A guanosine nucleotide } \\
\text { analog that inhibits } \\
\text { RNA synthesis }\end{array}$ & (Loginova et al., 2011) \\
\hline Favipiravir (Avigan) & RNA polymerase & $\begin{array}{l}\text { Inhibits } \\
\text { RNA-dependent RNA } \\
\text { polymerase (RdRp) }\end{array}$ & (Wang et al., 2020) \\
\hline Ribavirin & RNA polymerase & $\begin{array}{l}\text { Inhibits viral RNA } \\
\text { synthesis and mRNA } \\
\text { capping }\end{array}$ & (Khalili et al., 2020) \\
\hline Penciclovir & RNA polymerase & $\begin{array}{l}\text { Inhibits } \\
\text { RNA-dependent RNA } \\
\text { polymerase (RdRp) }\end{array}$ & (Wang et al., 2020) \\
\hline $\begin{array}{l}\text { Acyclovir fleximer } \\
\text { analogue }\end{array}$ & RNA polymerase & $\begin{array}{l}\text { Inhibits } \\
\text { RNA-dependent RNA } \\
\text { polymerase (RdRp) }\end{array}$ & $\begin{array}{l}\text { (Li and De Clercq, } \\
2020 \text { ) }\end{array}$ \\
\hline
\end{tabular}




\begin{tabular}{|c|c|c|c|}
\hline Drug candidate & Target & $\begin{array}{l}\text { Antiviral mechanism of } \\
\text { action }\end{array}$ & References \\
\hline Galidesivir & RNA polymerase & $\begin{array}{l}\text { Inhibits viral RNA } \\
\text { polymerase function by } \\
\text { terminating non } \\
\text { obligate RNA chain }\end{array}$ & $\begin{array}{l}\text { (Li and De Clercq, } \\
2020)\end{array}$ \\
\hline Ritonavir & Protease & Inhibits 3CLpro & (Stower, 2020) \\
\hline ASC09F & Protease & $\begin{array}{l}\text { A combination drug } \\
\text { containing ASC09 } \\
\text { (HIV protease } \\
\text { inhibitor) + ritonavir/ } \\
\text { Oseltamivir }\end{array}$ & $\begin{array}{l}\text { (Li and De Clercq, } \\
2020)\end{array}$ \\
\hline Camostat & Protease & $\begin{array}{l}\text { Serine protease } \\
\text { inhibitor with activity } \\
\text { against the host } \\
\text { TMPRSS2 protease } \\
\text { that is exploited on } \\
\text { 2019-nCoV }\end{array}$ & $\begin{array}{l}\text { (Li and De Clercq, } \\
2020)\end{array}$ \\
\hline Danoprevir & Protease & $\begin{array}{l}\text { A potent HCV protease } \\
\text { (NS3/4A) inhibitor }\end{array}$ & (Shah et al., 2020) \\
\hline Nelfinavir & Protease & $\begin{array}{l}\text { Inhibits } \\
\text { chymotrypsin-like } \\
\text { protease (3CLpro) }\end{array}$ & (Xu et al., 2020) \\
\hline Colistin & Protease & $\begin{array}{l}\text { Inhibits } \\
\text { chymotrypsin-like } \\
\text { protease (3CLpro) }\end{array}$ & (Liu and Wang, 2020) \\
\hline Valrubicin & Protease & $\begin{array}{l}\text { Inhibits } \\
\text { chymotrypsin-like } \\
\text { protease (3CLpro) }\end{array}$ & (Liu and Wang, 2020) \\
\hline Icatibant & Protease & $\begin{array}{l}\text { Inhibits } \\
\text { chymotrypsin-like } \\
\text { protease (3CLpro) }\end{array}$ & (Liu and Wang, 2020) \\
\hline Bepotastine & Protease & $\begin{array}{l}\text { Inhibits } \\
\text { chymotrypsin-like } \\
\text { protease (3CLpro) }\end{array}$ & (Liu and Wang, 2020) \\
\hline Epirubicin & Protease & $\begin{array}{l}\text { Inhibits } \\
\text { chymotrypsin-like } \\
\text { protease (3CLpro) }\end{array}$ & (Liu and Wang, 2020) \\
\hline Epoprostenol & Protease & $\begin{array}{l}\text { Inhibits } \\
\text { chymotrypsin-like } \\
\text { protease (3CLpro) }\end{array}$ & (Liu and Wang, 2020) \\
\hline Vapreotide & Protease & $\begin{array}{l}\text { Inhibits } \\
\text { chymotrypsin-like } \\
\text { protease (3CLpro) }\end{array}$ & (Liu and Wang, 2020) \\
\hline Rupintrivir & Protease & $\begin{array}{l}\text { Inhibits } \\
\text { chymotrypsin-like } \\
\text { protease (3CLpro) }\end{array}$ & (Liu and Wang, 2020) \\
\hline Lopinavir & Protease & $\begin{array}{l}\text { Inhibits } \\
\text { chymotrypsin-like } \\
\text { protease (3CLpro) }\end{array}$ & (Stower, 2020) \\
\hline
\end{tabular}




\begin{tabular}{|c|c|c|c|}
\hline Drug candidate & Target & $\begin{array}{l}\text { Antiviral mechanism of } \\
\text { action }\end{array}$ & References \\
\hline Ebselen & Protease & $\begin{array}{l}\text { Inhibits } \\
\text { chymotrypsin-like } \\
\text { protease (3CLpro) }\end{array}$ & (Jin et al., 2020) \\
\hline Cinanserin & Protease & $\begin{array}{l}\text { Inhibits } \\
\text { chymotrypsin-like } \\
\text { protease (3CLpro) }\end{array}$ & (Zhang and Liu, 2020) \\
\hline Flavonoids & Protease & $\begin{array}{l}\text { Inhibits } \\
\text { chymotrypsin-like } \\
\text { protease (3CLpro) }\end{array}$ & (Zhang and Liu, 2020) \\
\hline Beclabuvir & Protease & $\begin{array}{l}\text { Inhibits } \\
\text { chymotrypsin-like } \\
\text { protease (3CLpro) }\end{array}$ & (Talluri, 2020) \\
\hline Saquinavir & Protease & $\begin{array}{l}\text { Inhibits } \\
\text { chymotrypsin-like } \\
\text { protease (3CLpro) }\end{array}$ & (Talluri, 2020) \\
\hline$\alpha$ - ketoamide & Protease & $\begin{array}{l}\text { Inhibits } \\
\text { chymotrypsin-like } \\
\text { protease (3CLpro) }\end{array}$ & (Zhang et al., 2020b) \\
\hline Hesperidin & Protease & $\begin{array}{l}\text { Inhibits } \\
\text { chymotrypsin-like } \\
\text { protease (3CLpro) }\end{array}$ & (Adem et al., 2020) \\
\hline $\begin{array}{l}\text { Angiotensin II human } \\
\text { acetate }\end{array}$ & Protease & $\begin{array}{l}\text { Inhibits } \\
\text { chymotrypsin-like } \\
\text { protease (3CLpro) }\end{array}$ & (Contini, 2020) \\
\hline GHRP-2 & Protease & $\begin{array}{l}\text { Inhibits } \\
\text { chymotrypsin-like } \\
\text { protease (3CLpro) }\end{array}$ & (Contini, 2020) \\
\hline Indinavir & Protease & $\begin{array}{l}\text { Inhibits } \\
\text { chymotrypsin-like } \\
\text { protease (3CLpro) }\end{array}$ & (Contini, 2020) \\
\hline Cobicistat & Protease & $\begin{array}{l}\text { Inhibits } \\
\text { chymotrypsin-like } \\
\text { protease (3CLpro) }\end{array}$ & (Contini, 2020) \\
\hline Atazanavir & Protease & $\begin{array}{l}\text { Inhibits } \\
\text { chymotrypsin-like } \\
\text { protease (3CLpro) }\end{array}$ & (Contini, 2020) \\
\hline Mycophenolic acid & Protease & $\begin{array}{l}\text { Inhibits papain-like } \\
\text { protease (PLpro) }\end{array}$ & $\begin{array}{l}\text { (Elfiky and Ibrahim, } \\
2020 \text { ) }\end{array}$ \\
\hline Grazoprevir & Protease & $\begin{array}{l}\text { Inhibits papain-like } \\
\text { protease (PLpro) }\end{array}$ & $\begin{array}{l}\text { (Elfiky and Ibrahim, } \\
2020)\end{array}$ \\
\hline Formoterol & Protease & $\begin{array}{l}\text { Inhibits papain-like } \\
\text { protease (PLpro) }\end{array}$ & (Arya et al., 2020) \\
\hline Telaprevir & Protease & $\begin{array}{l}\text { Inhibits papain-like } \\
\text { protease (PLpro) }\end{array}$ & $\begin{array}{l}\text { (Elfiky and Ibrahim, } \\
2020)\end{array}$ \\
\hline Diarylheptanoids & Protease & $\begin{array}{l}\text { Inhibits papain-like } \\
\text { protease (PLpro) }\end{array}$ & (Zhang and Liu, 2020) \\
\hline
\end{tabular}




\begin{tabular}{|c|c|c|c|}
\hline Drug candidate & Target & $\begin{array}{l}\text { Antiviral mechanism of } \\
\text { action }\end{array}$ & References \\
\hline $\begin{array}{l}\text { Darunavir/cobicistat } \\
\text { alone or with } \\
\text { lopinavir/ritonavir }\end{array}$ & Protease & $\begin{array}{l}\text { An HIV-1 protease and } \\
\text { cytochrome P } 450 \\
\text { (CYP) } 3 \text { A enzyme } \\
\text { inhibitors }\end{array}$ & (Zhai et al., 2020) \\
\hline Ikarugamycin & ACE2 & $\begin{array}{l}\text { ACE2 inhibitors that } \\
\text { block the site of viral } \\
\text { spike protein } \\
\text { interaction }\end{array}$ & (Yang et al., 2020) \\
\hline Molsidomine & ACE2 & $\begin{array}{l}\text { Effective on the genes } \\
\text { co-expressed with } \\
\text { ACE2 }\end{array}$ & (Yang et al., 2020) \\
\hline Eriodictyol & ACE2 & $\begin{array}{l}\text { Binding potency to } \\
\text { viral S-protein at its } \\
\text { host receptor or to the } \\
\text { S protein-human ACE2 } \\
\text { interface }\end{array}$ & $\begin{array}{l}\text { (Smith and Smith, } \\
2020)\end{array}$ \\
\hline Nitrofurantoin & ACE2 & $\begin{array}{l}\text { Binding potency to } \\
\text { viral S-protein at its } \\
\text { host receptor or to the } \\
\text { S protein-human ACE2 } \\
\text { interface }\end{array}$ & $\begin{array}{l}\text { (Smith and Smith, } \\
2020 \text { ) }\end{array}$ \\
\hline Cepharanthine & ACE2 & $\begin{array}{l}\text { Binding potency to } \\
\text { viral S-protein at its } \\
\text { host receptor or to the } \\
\text { S protein-human ACE2 } \\
\text { interface }\end{array}$ & $\begin{array}{l}\text { (Smith and Smith, } \\
2020)\end{array}$ \\
\hline Baricitinib & Kinase & $\begin{array}{l}\text { Janus-associated kinase } \\
\text { (JAK) inhibitor which } \\
\text { is an important } \\
\text { regulator of } \\
\text { clathrin-mediated } \\
\text { endocytosis. }\end{array}$ & $\begin{array}{l}\text { (Richardson et al., } \\
2020)\end{array}$ \\
\hline Ruxolitinib & Kinase & $\begin{array}{l}\text { Janus-associated kinase } \\
\text { (JAK) inhibitor } \\
\text { blocking } \\
\text { ACE2-mediated } \\
\text { endocytosis }\end{array}$ & (Stebbing et al., 2020) \\
\hline Nitazoxanide & Interferon response & $\begin{array}{l}\text { Induces the host innate } \\
\text { immune response to } \\
\text { produce interferons }\end{array}$ & (Wang et al., 2020) \\
\hline Nafamostat & Spike glycoprotein & $\begin{array}{l}\text { Inhibits membrane } \\
\text { fusion }\end{array}$ & (Wang et al., 2020) \\
\hline Teicoplanin & Cathepsin L & $\begin{array}{l}\text { Antibiotic inhibiting } \\
\text { the low-pH cleavage of } \\
\text { the viral spike protein } \\
\text { by cathepsin L in the } \\
\text { late endosomes }\end{array}$ & (Zhang et al., 2020a) \\
\hline
\end{tabular}




\begin{tabular}{|c|c|c|c|}
\hline Drug candidate & Target & $\begin{array}{l}\text { Antiviral mechanism of } \\
\text { action }\end{array}$ & References \\
\hline Ciclesonide & Endoribonuclease & $\begin{array}{l}\text { An approved } \\
\text { corticosteroid that } \\
\text { inhibit replication via } \\
\text { inhibition of viral } \\
\text { nsp15 }\end{array}$ & $\begin{array}{l}\text { (Matsuyama et al., } \\
2020)\end{array}$ \\
\hline Camrelizumab & $\begin{array}{l}\text { Programmed cell death } \\
1 \text { (PD-1) }\end{array}$ & $\begin{array}{l}\text { A humanized } \\
\text { monoclonal antibody } \\
\text { (mAb) targeting PD-1 }\end{array}$ & $\begin{array}{l}\text { (AminJafari and } \\
\text { Ghasemi, 2020) }\end{array}$ \\
\hline Emtricitabine & Reverse transcriptase & $\begin{array}{l}\text { Non-nucleoside reverse } \\
\text { transcriptase inhibitor }\end{array}$ & (Harrison, 2020) \\
\hline Tenofovir & Reverse transcriptase & $\begin{array}{l}\text { Nucleotide reverse } \\
\text { transcriptase inhibitor }\end{array}$ & (Harrison, 2020) \\
\hline Azvudine & Reverse transcriptase & $\begin{array}{l}\text { Experimental reverse } \\
\text { transcriptase inhibitor } \\
\text { drug against } \\
\text { HIV-1/AIDS }\end{array}$ & (Harrison, 2020) \\
\hline Methylprednisolone & Nuclear receptors & $\begin{array}{l}\text { Synthetic corticosteroid } \\
\text { that binds to nuclear } \\
\text { receptors to dampen } \\
\text { proinflammatory } \\
\text { cytokines }\end{array}$ & (Harrison, 2020) \\
\hline IFN alpha-1b & Immunomodulation & $\begin{array}{l}\text { Bind to cellular } \\
\text { surfaces' receptors and } \\
\text { initiate JAK-STAT } \\
\text { signaling cascades }\end{array}$ & (Harrison, 2020) \\
\hline Interferon alfa- $2 \mathrm{a}$ & Immunomodulation & $\begin{array}{l}\text { Interferon alfa- } 2 \mathrm{~b} \text { is a } \\
\text { recombinant cytokine } \\
\text { with antiviral } \\
\text { properties; ribavirin is } \\
\text { a guanine derivative }\end{array}$ & $\begin{array}{l}\text { (Li and De Clercq, } \\
2020)\end{array}$ \\
\hline Tocilizumab & IL-6 receptor & $\begin{array}{l}\text { Approved } \\
\text { immunosuppressive } \\
\text { anti-IL-6 receptor mAb }\end{array}$ & (Harrison, 2020) \\
\hline Thalidomide & ND & $\begin{array}{l}\text { Regulating immunity, } \\
\text { inhibiting the } \\
\text { inflammatory cytokine } \\
\text { surge }\end{array}$ & (Dastan et al., 2020) \\
\hline Umifenovir (Arbidol) & ND & $\begin{array}{l}\text { Membrane fusion } \\
\text { inhibitor targeting viral } \\
\text { entry }\end{array}$ & $\begin{array}{l}\text { (Li and De Clercq, } \\
2020 \text { ) }\end{array}$ \\
\hline
\end{tabular}




\begin{tabular}{|c|c|c|c|}
\hline Drug candidate & Target & $\begin{array}{l}\text { Antiviral mechanism of } \\
\text { action }\end{array}$ & References \\
\hline $\begin{array}{l}\text { Chloroquine/ } \\
\text { hydroxychloroquine }\end{array}$ & ND & $\begin{array}{l}\text { 1. Elevate the pH of } \\
\text { acidic intracellular } \\
\text { organelles, such as } \\
\text { endosomes/lysosomes, } \\
\text { essential for membrane } \\
\text { fusion 2.Inhibit the entry } \\
\text { through changing the } \\
\text { glycosylation of ACE2 } \\
\text { receptor and spike } \\
\text { protein }\end{array}$ & $\begin{array}{l}\text { (Touret and de } \\
\text { Lamballerie, 2020) }\end{array}$ \\
\hline Fingolimod & ND & $\begin{array}{l}\text { Sphingosine-1- } \\
\text { phosphate receptor } \\
\text { regulator }\end{array}$ & $\begin{array}{l}\text { (Rosa and Santos, } \\
2020 \text { ) }\end{array}$ \\
\hline Dipyridamole & & $\begin{array}{l}\text { Adenosine deaminase } \\
\text { and phosphodiesterase } \\
\text { inhibitor }\end{array}$ & (Aly, 2020) \\
\hline
\end{tabular}

Table 2. Potential drug candidates for $2019-\mathrm{nCoV}$ in clinical trials and their status in April 2020 based on clinicaltrials.gov database.

\begin{tabular}{ll}
\hline ClinicalTrials.gov Identifier & Intervention \\
\hline NCT04321096 & Camostat Mesilate \\
NCT04324996 & Biological: NK cells,IL15-NK cells,NKG2D CAR-NK cells,ACE2 CAR-NK cells,... \\
NCT04276688 & Lopinavir/ritonavir; Ribavirin ; Interferon Beta-1B \\
NCT04280588 & Fingolimod \\
NCT04273529 & Thalidomide \\
NCT04288102 & Biological: MScs \\
NCT04317092 & Tocilizumab \\
NCT04321993 & Lopinavir/ritonavir; Hydroxychloroquine sulfate; Baricitinib (janus kinase inhibitor) ; Sarilum \\
NCT04313023 & PUL-042 Inhalation Solution \\
NCT04275245 & Meplazumab \\
NCT04279197 & Acetylcysteine \\
NCT04311177 & Losartan \\
NCT04292899 & Remdesivir \\
NCT04325633 & Naproxen \\
NCT04304313 & Sildenafil citrate \\
NCT04320615 & Tocilizumab (TCZ) \\
NCT04315896 & Hydroxychloroquine \\
NCT04317040 & CD24Fc \\
NCT04261270 & ASC09F+Oseltamivir; Ritonavir+Oseltamivir ; Oseltamivir \\
NCT04321616 & Hydroxychloroquine; Remdesivir \\
NCT04315298 & Sarilumab \\
NCT04324021 & Emapalumab \\
NCT04252274 & Darunavir and cobicistat \\
NCT04308317 & Tetrandrine \\
NCT04286503 & Carrimycin \\
NCT04254874 & Arbidol Hydrochloride combined with Interferon atomization \\
NCT04263402 & Methylprednisolone \\
& \\
&
\end{tabular}




\begin{tabular}{ll}
\hline ClinicalTrials.gov Identifier & Intervention \\
\hline NCT04252885 & Umifenovir (Arbidol) \\
NCT04255017 & Umifenovir (Arbidol); Oseltamivir; Lopinavir/ritonavir \\
NCT04291729 & Drug: Ganovo (Danoprevir )+ritonavir+/-Interferon nebulization \\
\hline
\end{tabular}

Table 3. Vaccine candidates for 2019- $\mathrm{nCoV}$ in clinical trials and their current status in April 2020 based on clinicaltrials.gov database.

\begin{tabular}{llll}
\hline ClinicalTrials.gov Identifier & ClinicalTrials.gov Identifier & Interventions & Mechanism of action \\
\hline NCT04283461 & mRNA-1273 & mRNA-1273 & Novel lipid nanoparticle (LNP)-encap \\
NCT04313127 & Ad5-nCoV & Ad5-nCoV & Adenovirus type 5 vector that expres \\
NCT04336410 & NO-4800 & NO-4800 & DNA plasmid encoding S protein del \\
NCT04276896 & LV-SMENP-DC & LV-SMENP-DC & Lentiviral vector system (NHP/TYF \\
NCT04299724 & Pathogen-specific aAPC & Pathogen-specific aAPC & aAPCs modified with lentiviral vecto \\
\hline
\end{tabular}

Table 4. Principle molecular targets of 2019-nCoV for drug discovery or design. ND: Not determined.

\begin{tabular}{lll}
\hline Viral cycle & Target & Antiviral drug \\
\hline Host attachment and entry & Host cell serine protease & Eriodictyol, Cepharanthine, \\
& receptor & Ergoloid, Nitrofurantoin \\
& Host tyrosine kinase receptor & ND \\
& ACE2 & ND \\
& Integrins & ND \\
& Spike protein & EK1C4 \\
Uncoating & Ion channel proteins & ND \\
Replicase Protein Expression & Papain-like proteinase (PLpro) & Mycophenolic acid, \\
& & Grazoprevir, Formoterol, \\
& & Telaprevir, Diarylheptanoids, \\
& & etc \\
& 3 C-like main protease (3CLpro) & Ritonavir, Nelfinavir, Lopinavir, \\
& & Ebselen, Cinanserin, \\
Replication of viral genome & RNA-dependent RNA & Ketoamide, Atazanavir, \\
& polymerase (RdRp) & Remdesivir, Baloxavir marboxil, \\
& & Triazavirin, Favipiravir \\
& & (Avigan), Ribavirin, \\
& & Penciclovir, Acyclovir fleximer \\
& & analogue, Galidesivir \\
Viral protein assembly & ND \\
& The pepticase & ND \\
& (PPIases) & \\
& Nucleoside analogs & Remdesivir, Favipiravir, \\
& Envelope protein (E protein) & ribavirin, 5-fluorouracil \\
& ORF7a & ND \\
\hline
\end{tabular}

\section{Figure legends}




\section{Figure 1}

The schematic diagram (left) (original in this paper) and the scanning electron micrograph (right) (Source: NIAID-RML) of the 2019-nCoV surface proteins

\section{Figure 2}

2019-n CoV cell cycle in host cells. The virus enters the target cells through direct membrane fusion (A) or a clathrin-mediated endosomal pathway (B). Binding of the surface unit of the S protein (S1) to angiotensinconverting enzyme 2 (ACE2) facilitates the viral attachment. Viral fusion is primed by TMPRSS2 and the active spike protein of 2019-nCoV acquire an RGD motif known to bind integrins. Spike glycoprotein RGD lies in the receptor-binding domain. Binding to integrin may play a supplemental role to ACE2 binding, like facilitating endocytosis by signaling through the integrin. This motif is absent in other coronaviruses. The viral RNA is unveiled by the effect of endosomal cathepsins at low $\mathrm{pH}$. Following, the replicase gene of the viral genome is translated into large polyproteins which are cleaved by the proteases to yield 16 nonstructural proteins (nsps). In consequence ofreplication, transcription and translation, viral nucleocapsids are assembled with genomic RNA and N protein in the cytoplasm, followed by budding into golgi intermediate compartment. Then, virions are released from the infected cell through exocytosis.

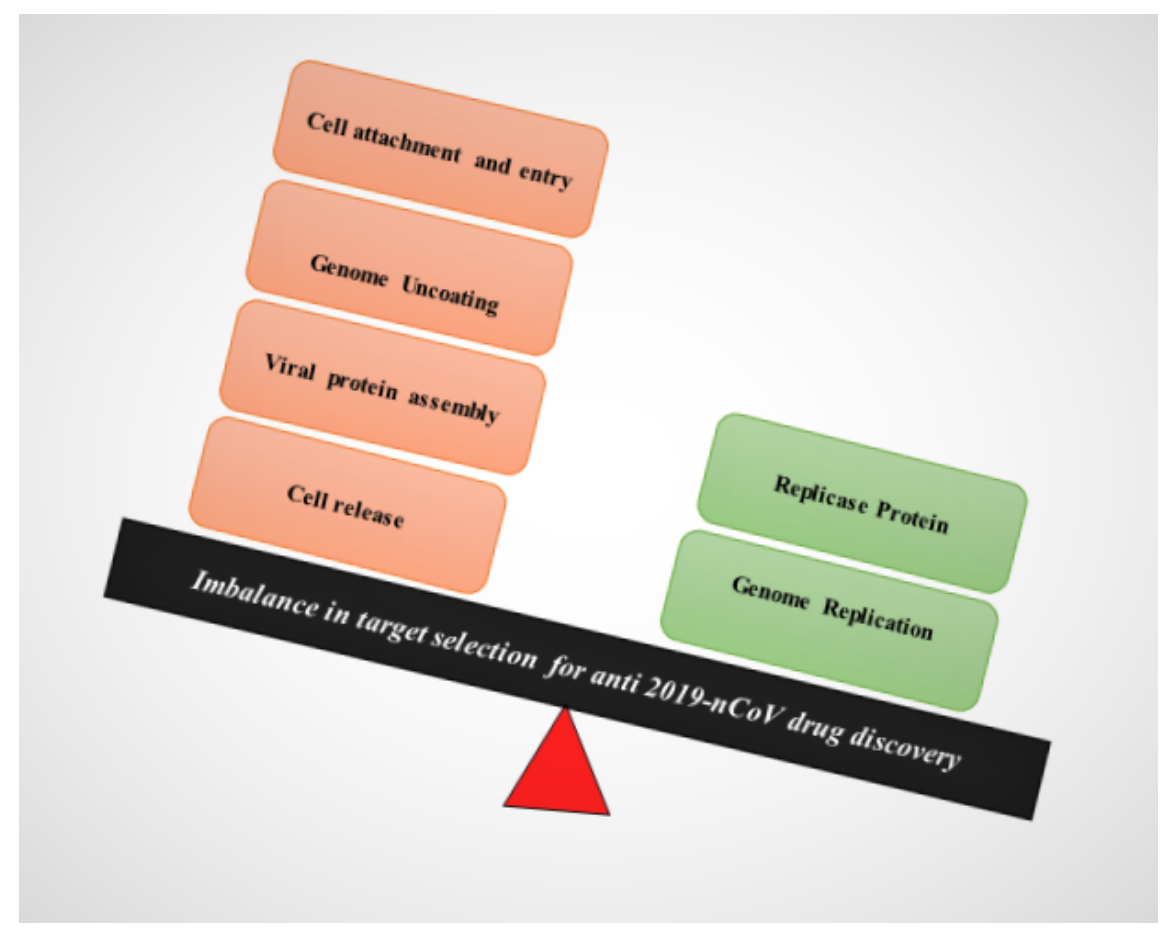



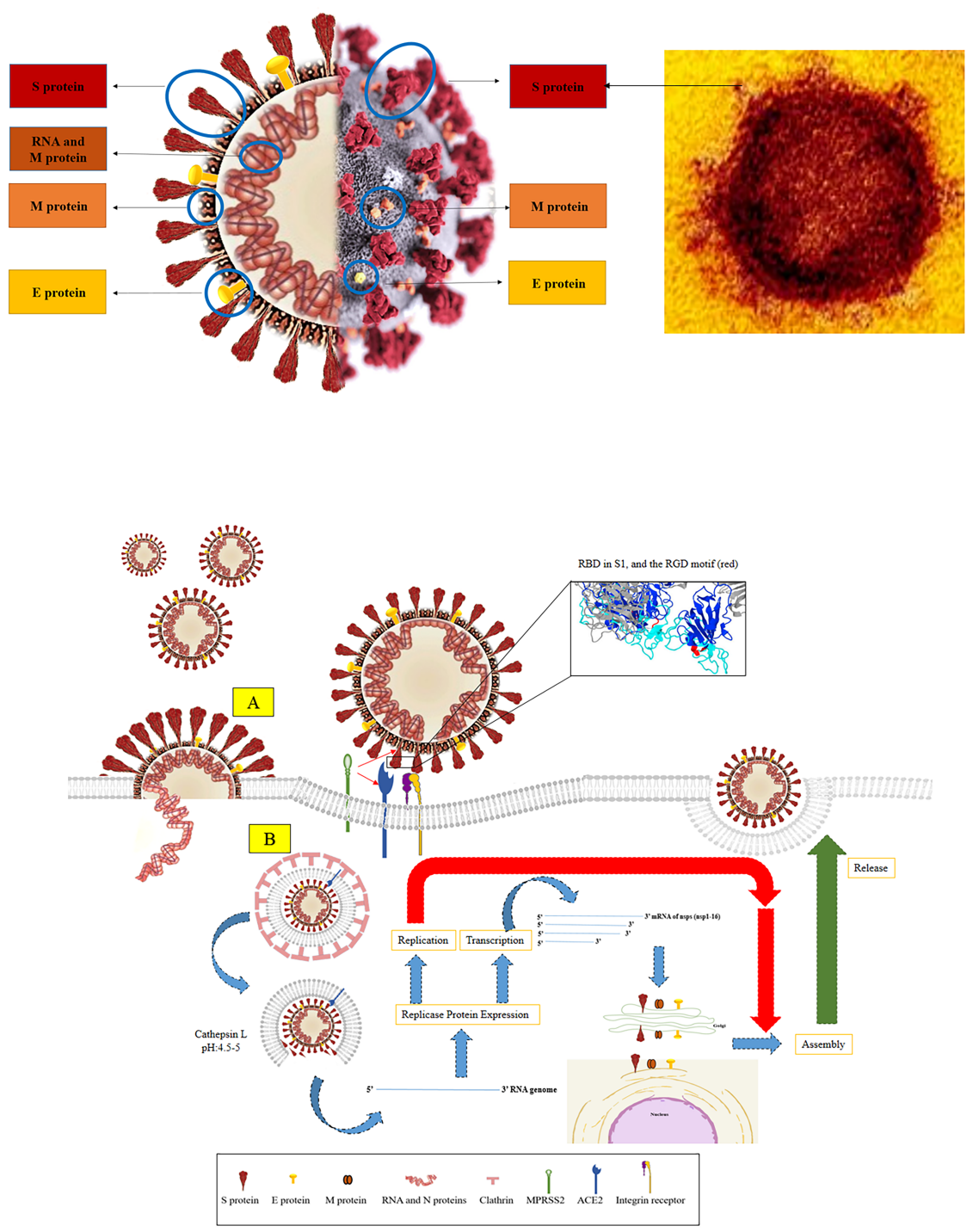